\title{
Intervention Model for Orphan's Emotional and Behavioral Problems: A Scoping Review
}

\author{
Yuli Isnaeni $^{1,2}(\mathbb{D})$, Sri Hartini ${ }^{3 *}$ (D), Carla Raymondalexas Marchira ${ }^{4}$ (D) \\ ${ }^{1}$ Department of Community Nursing, Universitas Aisyiyah, Yogyakarta, Indonesia; ${ }^{2}$ Student of Doctoral Program, Faculty of \\ Medicine, Public Health, and Nursing, Universitas Gadjah Mada, Yogyakarta, Indonesia; ${ }^{3}$ Department of Nursing, Faculty of \\ Medicine, Public Health, and Nursing, Universitas Gadjah Mada, Yogyakarta, Indonesia; ${ }^{4}$ Department of Psychiatric, Faculty of \\ Medicine, Public Health, and Nursing, Universitas Gadjah Mada, Yogyakarta, Indonesia
}

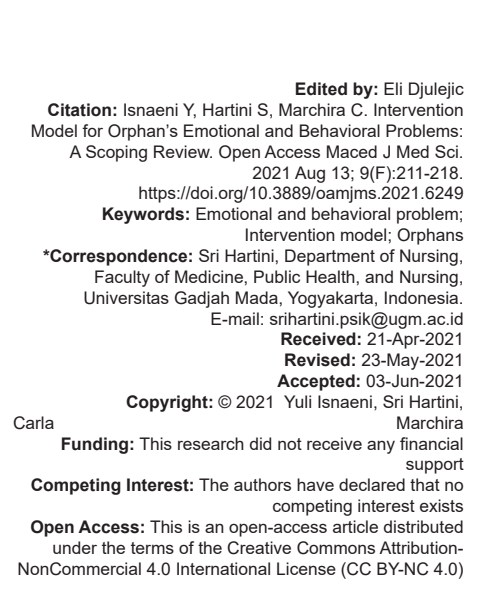

Abstract

BACKGROUND: As many as, $45 \%$ of orphaned children and adolescents living in orphanages experience behaviora and emotional problems. Several literature reviews on the intervention of emotional and behavioral problems in orphan children and adolescents have been widely conducted. However, there is paucity in the reviews of emotional and behavioral problem interventions in the orphan group based on the type of group approach used in published articles.

AIM: This study aimed to synthesize the results on the interventions of emotional and behavioral problems in orphan children and adolescents aged 7-20 years who live in institutions or orphanages.

METHODS: This research was a scoping review. This review used three databases comprising PubMed, Science Direct, and Wiley Library Online. The inclusion criteria were experimental research designs and cohort studies, published in the 2009-2019, discussed emotional and behavioral problem's intervention in orphan, and written in English. The exclusion criteria were that the research subjects had severe mental and psychosocial disorders such as autism, mental retardation, and mental disorders. The authors used three categories of keywords; the first keyword and its synonym were "intervention, treatment." The second keyword focused on behavioral problems, which was "behavioral difficulties," and the third keyword focuses on population and place, "orphan, institutions orphans, orphanages." The article selection stage is described in detail in the flow diagram of Preferred Reporting Items for Systematic Reviews and Meta-Analysis. The critical appraisal stage used the checklist from Joanna Briggs Institute.

RESULTS: Ten articles were found and selected for review. The main emotional and behavioral problems experienced by orphan children and adolescents include depression, anxiety, and low self-esteem, feelings of anger, and trauma. Other problems related, functional disorders, life satisfaction, the probability of suicide, and early (prodromal) symptoms of psychosis, also arise. There were six types of interventions given to overcome emotional and behavioral problems in orphan children and adolescents, but the interventions that are most often given are cognitive therapy, educational support, complementary, and alternative medicine. The approaches in groups that are often used in this review are the support group and the teaching-learning group. The combination of two or more approaches in one intervention can increase the success or effectiveness in overcoming emotional and behavioral problems.

CONCLUSIONS: Depression, anxiety, low self-esteem, feeling anger, and trauma are main problems for orphans. To address these emotional and behavior problems, it is necessary to combine several interventions and a combination of group-based approaches.

\section{Introduction}

Research [1] found as many as $40.35 \%$ of orphans and orphaned adolescents living in institutions experience behavioral problems and emotional problems. These complex problems with orphans living in orphanages have attracted the attention of social researchers and child welfare experts in the past new decades [2]. Social research in Cairo found that $64.35 \%$ of children and adolescents had behavioral disorders [3].

Placing orphans in orphanages provide a solution, but at the same time, it can cause new problems for children [4], [5]. The emergence of emotional and behavioral problems cannot be separated from the orphanage's role because this institution often implements "structural neglect" which is thought to be the caused by limited physical resources, unfavorable parenting, and instability as well as inadequate social and emotional interactions between caregivers and children [6], [7]. While many serious cases occur, the care and support provided by the orphanage are limited to biological needs such as nutrition, basic health, and education [8].

Some of the emotional and behavioral problems that often arise are aggressive behavior, and many orphans in institutions have higher levels of depression and anxiety than orphans who are raised in a family 
environment [9], [10]. These behavioral and emotional problems have an impact on the development of the child as a whole, particularly on academic results and social constraints in adulthood [11]. Another study found that care in these social institutions has a negative impact on emotional development and regulation in younger children (pre-school) and the length of stay at the institution determines the severity of cognitive development, especially in children placed in nursing homes since birth [12].

Several research results recommend prevention and management of behavioral problems and emotional problems of children in an orphanage, including early detection of children's behavioral and emotional problems, ongoing treatment from the start of entering the institution, increasing warmth in care [13], and providing material and psychosocial support [6], [14]. The choice of group approach in intervention is very important to consider based on the characteristics of the orphan group. Support groups focus on increasing adaptation after experiencing a crisis of losing one or both parents, such as self-help groups that provide emotional support among group members. Teachinglearning is conducted to disseminate information, techniques or skills, with socialization-centered approaches to improve adaptation abilities and social skills as well as task or planning oriented groups which are groups formed to complete certain tasks or responsibilities [15].

There have been many reviews of various models of behavior problem interventions in orphans living in orphanages, but the existing reviews have not specifically addressed the types of interventions based on group approaches and the types of behavior problems experienced by orphans. In particular, this review aimed to find out:

1. The behavioral and emotional problems often experienced by orphan adolescents

2. The types of interventions given to orphan adolescents who experienced emotional and behavioral problems

3. The type of group approach used in the intervention given to orphan adolescents groups who experience behavioral and emotional problems.

\section{Methods}

The intervention model for orphan's emotional and behavioral problem was review applied the Arksey and O'Malley's framework including (1) identifying research questions, (2) identifying relevant studies, (3) study selection, (4) charting the data, and (5) collating, summarizing, and reporting results (Levac, Colquhoun and O'Brien, 2010).

\section{Search strategy}

The authors determined research questions based on research objectives with the help of the patient problem or population intervention comparison outcomes (PICO) framework. The PICO framework is generally used in evidence-based clinical practice and is considered a strategy that assists in the preparation of research questions [16]. The PICO framework consists of four concepts, which are Patient, Problem or Population (patient or population problems), Intervention, Comparison (comparisons if any), and Outcomes (results or effects of intervention). The PICO framework is presented in Table 1.

Table 1: PICO framework

\begin{tabular}{llll}
\hline Patient problem or population & Intervention & Comparison & Outcomes \\
\hline Children and adolescent & Therapy & ${ }^{*}$ No treatment & Behavior problem or \\
orphaned with emotional and & Intervention & & externalizing problem \\
behavioral problem & Model & & Emotional problem or \\
& Support & & internalizing problem \\
\hline
\end{tabular}

Search for articles was conducted on journals published between 2009 and 2019, through three databases: (1) Medline (via PubMed), (2) ScienceDirect, and (3) Wiley Online Library. The author used three categories of keywords; the first keyword and its synonym were "intervention, treatment." The second keyword focused on behavioral problems, which was "behavioral difficulties, and the third keyword focuses on population and place, "orphan, institutions orphans, orphanages." These keywords were connected by logical connectors OR and AND. We used Boolean OR for per-keyword synonym alternatives and use Boolean AND to link the primary keywords. Journals that are presented in free full text and only in English were included in this review. The authors used the Zotero software to collect articles and select relevant articles according to research questions and research objectives. The authors used Preferred Reporting Items for Systematic Reviews and Meta-Analyses (PRISMA) guidelines [17] to describe the search and selection of articles. The PRISMA flow diagram is presented in Figure 1

\section{Inclusion criteria}

The inclusion criteria in this study were as follows: (1) Articles published in the 2009-2019 period; (2) articles that discuss behavioral problems and emotional problems intervention in Orphan, (3) original research or research paper or research article; (4) articles are presented in English; and (5) articles with experimental research designs and cohort studies.

\section{Exclusion criteria}

Articles were excluded if it is found that the research subjects had severe mental and psychosocial disorders such as autism, mental retardation, and mental disorders. 


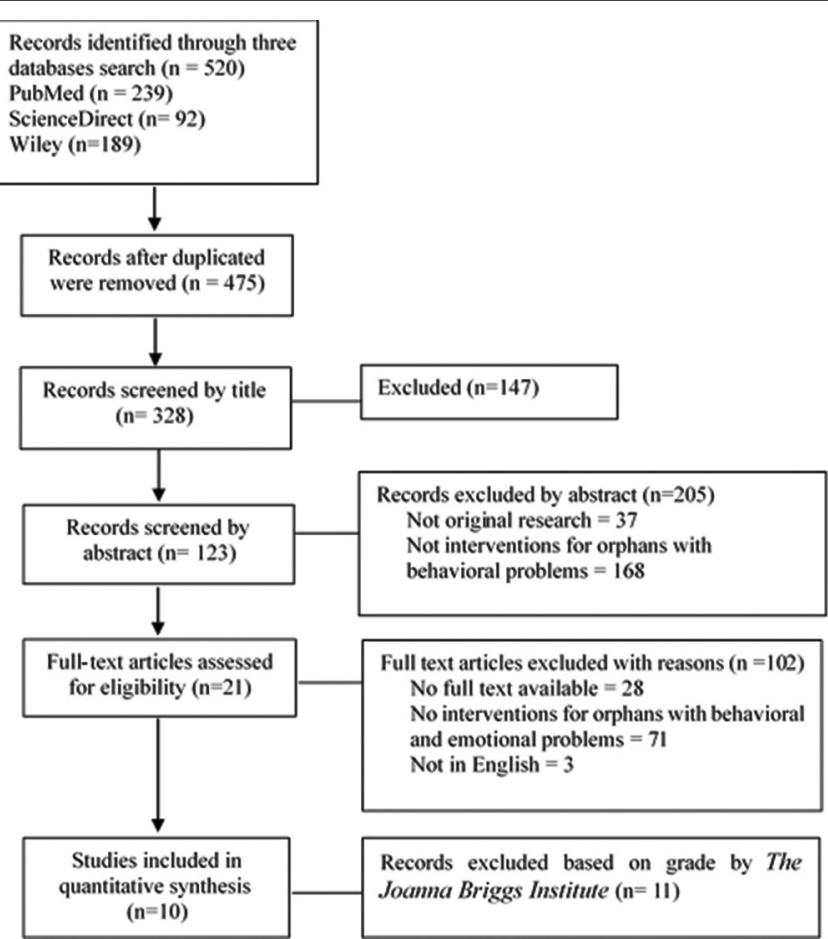

Figure 1: Flow diagram of screening, selection process, and inclusion of studies based on the preferred items for systematic reviews and meta-analyses guidelines [17]

\section{Search outcomes}

The PRISMA results show that there were 520 articles obtained from three databases. The selection of articles was performed based on predetermined inclusion and exclusion criteria. This study obtained 21 relevant articles and from these results a critical appraisal was conducted using the Joanna Briggs Institute (JBI) handbook [18].

The selection phase of research journals is presented in the PRISMA diagram which is shown in Figure 1.

\section{Quality appraisal}

Three reviewers read 21 articles while conducting a critical appraisal using the JBI checklist for randomized control trials, quasi-experimental studies, and cohort studies. The consideration used to determine the quality article of cohort studies that fit into the synthesis were as follows: Sample recruitment, exposures measures, confounding factors, outcomes measures, follow-up time, and statistical analysis. The considerations used to determine the quality of articles of quasi-experimental studies that fit into the synthesis phase were as follows: Clear of cause and effect, participants included the presence of the control group, the presence of multiple measurements of the outcome (both pre and post), the follow-up, reliability of outcome measures, and statistical analysis. Meanwhile, the consideration used to determine the quality article of random controlled trials (RCT) were as follows: Accuracy of randomization, the confidentiality of the treatment group, baseline similarity of treatment group, the presence of blind treatment, the presence of follow-up, accuracy of outcomes measured, and statistical analysis. The results of the critical appraisal obtained 10 articles to be continued in the extraction and analysis stages.

\section{Data extraction and analysis}

Data extraction was conducted on 10 articles that were found in the previous stage. The grouping of information from each article was broken down into several sections, referring to Peters et al. [19] (Peters et al., 2015), which are as follows: (1) Author, (2) year of publication, (3) source country of origin, (4) Purpose, (5) study population and sample size, (6) research methodology, (7) type of intervention, (8) duration of intervention, (9) means of measurement of results, and (10) findings relevant to the research question. This extraction data are shown in Tables 2-4.

Table 2: Characteristics of the studies

\begin{tabular}{llll}
\hline Author(s) & Year of publication & Country & Continent \\
\hline Zhao et al. & 2010 & China & Asia \\
Ojiambo and Bratton & 2014 & Uganda & Africa \\
Cluver et al. & 2015 & Haiti & America \\
Rouholamini et al. & 2016 & Persia & Asia \\
Kane et al. & 2016 & Zambia & Africa \\
Tejvani $e t$ al. & 2017 & India & Asia \\
Green et al. & 2018 & Kenya & Africa \\
Ozturk and Ekinci & 2018 & Turkey & Asia \\
Rahayu et al. & 2018 & Indonesia & Asia \\
Mohammadzadeh et al. & 2019 & Malaysia & Asia \\
\hline
\end{tabular}

Descriptive analysis method used to extract research results from 10 articles regarding the interventions on orphans with emotional and behavioral problems. The results of this analysis were then presented in tabular form (Levac, Colquhoun and O'Brien, 2010). The main author compiled and designed this review, then all the authors collected data and conducted data analysis and interpreted the data and discussed until the final review report was compiled of the 10 articles.

\section{Results}

\section{Descriptive characteristic of the studies}

A primary search of the databases resulted 520 articles and after duplicated was removed became 475 . One hundred and forty-seven articles were excluded because by title, abstract, and with reason (not full text, not emotional and behavior intervention, and not in English), remaining 10 articles after being assessed JBI appraisal.

The author has found 10 selected articles, published between 2009 and 2019. There are six studies conducted in Asia, three studies in Africa, and 
Table 3: Summary of behavioral intervention problems

\begin{tabular}{|c|c|c|c|c|c|}
\hline \multirow[t]{2}{*}{ Author(s), year of publication } & \multirow[t]{2}{*}{ Purpose } & \multicolumn{3}{|c|}{ Sample } & \multirow[t]{2}{*}{ Measurement result } \\
\hline & & $\mathrm{n}$ & Location & Sex/age & \\
\hline Zhao et al., 2010 & $\begin{array}{l}\text { To compare psychological symptoms among } \\
\text { orphans with multiple AIDS }\end{array}$ & 176 & 4 selected orphanages & $\begin{array}{l}\text { Female } \\
\text { Male } \\
\text { Children }\end{array}$ & $\begin{array}{l}\text { Depression, loneliness, anxiety, anger (child } \\
\text { psychological problems }\end{array}$ \\
\hline Ojiambo and Bratton, 2014 & $\begin{array}{l}\text { To identify the effect of group activity play } \\
\text { therapy (GAPT) intervention on behavior } \\
\text { problems in pre-adolescent orphans }\end{array}$ & 42 & $\begin{array}{l}\text { Selected elementary } \\
\text { school }\end{array}$ & $\begin{array}{l}\text { Female } \\
\text { Male } \\
\text { Children }\end{array}$ & $\begin{array}{l}\text { Anxiety, depression, stress symptoms, } \\
\text { and emotional problems (internalizing } \\
\text { problems) and aggression and conduct } \\
\text { problems(externalizing problems) }\end{array}$ \\
\hline Cluver et al.., 2015 & $\begin{array}{l}\text { To identify whether yoga exercise can reduce } \\
\text { trauma-related disorders and emotional and } \\
\text { behavioral problems }\end{array}$ & 76 & 2 selected orphanages & $\begin{array}{l}7-17 \text { years old } \\
\text { (adolescents) }\end{array}$ & Trauma and behavioral problems \\
\hline Rouholamini et al., 2016 & $\begin{array}{l}\text { To determine the effectiveness of spiritual } \\
\text { components training on the life satisfaction of } \\
\text { orphan adolescents }\end{array}$ & 20 & selected orphanages & $\begin{array}{l}\text { Female } \\
12-15 \text { years old }\end{array}$ & Life satisfaction \\
\hline Kane et al., 2016 & $\begin{array}{l}\text { To explores moderate factors in response to } \\
\text { TF-CBT treatment among a sample of orphans } \\
\text { and vulnerable children (OVC) }\end{array}$ & 257 & orphanages & Children & Trauma and functional disorder \\
\hline Tejvani et al.., 2017 & $\begin{array}{l}\text { To identify the effect of yoga interventions on } \\
\text { psychological problems }\end{array}$ & 34 & Selected orphanages & $\begin{array}{l}\text { Male: } 27 \\
\text { Female: } 7 \\
\text { 12-20 years old }\end{array}$ & Depression, anxiety, and self-esteem \\
\hline Green et al., 2019 & $\begin{array}{l}\text { To examine the effect of school support } \\
\text { interventions on mental health in orphan } \\
\text { adolescent }\end{array}$ & 835 & $\begin{array}{l}26 \text { selected elementary } \\
\text { schools }\end{array}$ & $\begin{array}{l}\text { Male } \\
\text { Female } \\
\text { Children and } \\
\text { adolescents }\end{array}$ & Depression \\
\hline Ozturk and Ekinci, 2018 & $\begin{array}{l}\text { To determine the effect of structured education } \\
\text { on self-esteem and the probability of suicide }\end{array}$ & 30 & Selected orphanage & $\begin{array}{l}\text { Male } \\
\text { Adolescents }\end{array}$ & Self-esteem, probability of suicide \\
\hline Rahayu et al., 2018 & $\begin{array}{l}\text { To determine the effect of cognitive therapy } \\
\text { and psychoeducation on prodromal psychosis } \\
\text { and self-esteem of adolescents }\end{array}$ & 77 & Orphanage & $\begin{array}{l}\text { Male } \\
\text { Female } \\
\text { Adolescents }\end{array}$ & Early symptoms of psychosis and self-esteem \\
\hline Mohammadzadeh et al., 2019 & $\begin{array}{l}\text { To determine whether life skills based } \\
\text { interventions can improve emotional health } \\
\text { and self-esteem in adolescents }\end{array}$ & 271 & 8 selected orphanage & $\begin{array}{l}\text { Male } \\
\text { Female } \\
13-18 \text { years old }\end{array}$ & $\begin{array}{l}\text { Depression, anxiety, and stress (emotional } \\
\text { problems) and self-esteem }\end{array}$ \\
\hline
\end{tabular}

Table 4: Summary of behavioral intervention models based on the group approach

\begin{tabular}{|c|c|c|c|}
\hline Group approach & Reference & Type of intervention & Name of intervention \\
\hline \multirow[t]{6}{*}{ Support group } & Ozturk and Ekinci, 2018 & Cognitive behavior therapy (CBT) & The structure education \\
\hline & Green et al., 2019 & Educational support & School support intervention \\
\hline & Rouholamini et al., 2016 & Spiritual training & Spiritual component training \\
\hline & Zhao et al., 2010 & Psychological support & Family-based care \\
\hline & Kane et al., 2016 & CBT & Trauma focus - CBT \\
\hline & Ojiambo and Bratton, 2014 & Mental health intervention & Group activity play therapy (GAPT) \\
\hline \multirow[t]{2}{*}{ Self-help group } & Mohammadzadeh et al., 2019 & Life skill-based intervention & Life skill education program \\
\hline & Ojiambo and Bratton, 2014 & Mental health intervention & GAPT \\
\hline \multirow[t]{5}{*}{ Teaching-learning group } & Ojiambo and Bratton, 2014 & Mental health intervention & GAPT \\
\hline & Rouholamini et al., 2016 & Spiritual training & Spiritual component training \\
\hline & Mohammadzadeh et al., 2019 & Life skill-based intervention & Life skill education program \\
\hline & Culver et al., 2015 & Complementary and alternative medicine (CAM) & Yoga intervention \\
\hline & Tejvani et al., 2017 & CAM & Yoga-based intervention \\
\hline Socialization-centered group & Ozturk and Ekinci, 2018 & CBT & The structure education \\
\hline \multirow[t]{2}{*}{ Task/directed oriented group } & Ojiambo and Bratton, 2014 & Mental health intervention & GAPT \\
\hline & Ozturk and Ekinci, 2018 & CBT & The structure education \\
\hline
\end{tabular}

one study in America, which are shown in Table 1. This review study was conducted on findings in selected orphanages and selected primary schools, and several studies that divided respondents according to gender. In general, the research under review aimed to determine the effect of intervention on orphan emotional and behavior such as depression, trauma, feelings of loneliness, life satisfaction, anxiety, selfesteem, suicidal thoughts, mental health, prodromal psychological signs, and stress. From several studies, there are additional findings and respondents who were involved in the intervention, including teachers, parents, and orphanages, as listed in Table 2.

\section{Emotional behavioral problems (EBP)}

Of the 10 selected articles, one article describes EBP in the externalizing problem and internalizing problem categories, three studies mention that EBP uses the categories of psychological problems (depression, loneliness, anxiety, and anger), behavioral problems, and emotional problems (depression, anxiety, and stress), while six other articles mention separately for each component that makes up EBP, which are depression, anxiety, and self-esteem. In addition to the main outcomes, problems related to EBP were also found, including functional disorders, life satisfaction, the probability of suicide, and early symptoms (prodromal) of psychotic mental disorders. The highest EBPs experienced by orphan adolescents are depression, anxiety, and low self-esteem, followed by feelings of anger, depression, and trauma, Table 3.

\section{Types of group-based EBP intervention}

Of the 10 selected articles, there are six types of interventions or models of care to overcome EBP as follows:

1. Educational support [8], [24]

2. Spiritual support [21]

3. Play therapy [14]

4. Complementary and alternative medicine [20], [23] 
5. $\quad$ Family support [2]

6. Cognitive therapy [22], [25], [26].

From these selected articles, the most frequently used therapy is cognitive therapy, followed by educational support and complementary and alternative medicine, while the ones that are rarely used are family support, spiritual support, and play therapy.

\section{The types of group approach used in the EBP intervention}

Of the 10 articles selected, they were classified into the types of group approaches used in interventions to overcome EBP challenges consisting of:

$\begin{array}{ll}\text { 1. } & \text { Support group [2], [14], [21], [22], [24], [25] } \\ \text { 2. } & \text { Self-help group [8], [14] } \\ \text { 3. } & \text { Teaching-learning group [4], [8], [14], [21], [23], [26] } \\ \text { 4. } & \text { Socialization-centered group [25] } \\ \text { 5. } & \text { Task-/planning-oriented group [14], [25]. } \\ & \text { From these selected articles, the approaches }\end{array}$

in groups that are often used in this review are support groups and teaching-learning groups, followed by selfhelp groups, task-/planning-oriented groups, and those that are rarely used in socialization centered groups. This approach is used in a combination of 2-4 approaches at once in behavioral interventions. Group activity play therapy (GAPT) uses four group approaches at the same time in implementing its intervention, namely, support groups, self-help groups, teaching-learning groups, and task-/planning-oriented groups.

\section{Discussion}

The first finding obtained from this review is that the EBP or emotional and behavioral problems most often experienced by orphans are depression, anxiety, and low self-esteem. This problem is in line with research in Africa, which showed that orphan adolescents have a higher incidence of grieving problems, post-traumatic stress, depression, suicidal thoughts, anxiety, behavior problems, and negative outlook, than non-orphan adolescents [28], [29], [30], [31]. More specifically, this study is also in line with Erango and Ayka [32] which stated that $59 \%$ of children experience self-esteem problems followed by emotional problems including anxiety as much as $14.73 \%$ [7] and at least $12.7 \%$ experience depression [7].

The psychosocial development stage of adolescents aged 12-17 years is in the period of identity versus identity confusion [33] or is a critical period that must be surpassed in a person's development. If they do not get the attention of the parents, because of the religious or social condition experienced by the children, there will be more severe emotional and behavioral problems compared to adolescents who still have both supportive parents. The problems experienced are in the form of unstable emotions, tendency to have many social problems, lack self-confidence, and are anxious and restless because of experiencing inner contradictions [34]. For this condition for adolescents, it takes close friends or peers (peer groups) to get security support, guidance, and outpouring because they have the same characteristics and can be relied on to understand what is going on. Therefore, group forums are more appropriate as an approach in overcoming emotional and behavioral problems in adolescents.

Orphan interventions with EBP can be given individually or in groups. Giving group-based or peer group interventions are more effective than individual approaches, because group members have the opportunity to share about the problems and challenges that they are facing. The main goal about learning in this group of orphan adolescents is they learn from each other how to deal with the grief of the death of one or both of their parents and learn socialization skills that will help them later in life [35]. Game therapy, which is conducted in groups for adolescents, shows significant results in increasing low self-esteem, with games can help in creating communication, cooperation, and being able to withstand stress [36].

In general, the most frequently used intervention for EBP is cognitive behavior therapy (CBT). This intervention has strong evidence based on various age ranges and types of clinical disorders or types of problems experienced, including behavioral and emotional problems [37], [38]. Modification or development of CBT, which is trauma focusCBT (TF-CBT), showed positive results in reducing symptoms of post-traumatic stress disorder in orphans after 6 months of the departure or death of their parents [39]. The main keys to this intervention are in psychoeducation, coping skills, identification of feelings, gradual exposure, cognitive processes related to beliefs, and involvement of caregivers. Implementation of TF-CBT can be performed in schools, clients' homes, and in individual and group therapy settings.

Efforts to overcome EBP often have to integrate two or more types of interventions that are used together, which aim to be more on target and more effective [37] because EBP itself is a collection of several emotional and behavioral problems. In addition to cognitive therapy, the use of spiritual building, support group therapy, application of discipline, extracurricular play activities, and parental assistance in the family are conducted as an effort to overcome the problem of poor behavior in orphaned children and adolescents of single parents in school settings. The role of religion or spirituality in the welfare of orphans is rarely found as in this study, but available empirical evidence has suggested that religion and spirituality have an important role in controlling emotions and providing positive encouragement to further improve 
personal qualities [40]. Play therapy is one of the most important methods used to train children's social skills. It can also build connectivity and help solve behavioral problems for orphans in orphanages [41]. One of the characteristics of orphans is feeling insecure about their abilities, which is the main cause of most withdrawals from the surrounding environment. Hence, play therapy can build social interactions and friendships between members in the groups [42].

Yoga is a traditional technique that promotes personal health and well-being. Yoga has scientifically positive effects on emotional and cognitive functions, besides having a direct impact on motor or physical in children and adults. The Purohit research conducted by RCT showed that 3 months of time were found to be beneficial for orphaned adolescents in improving their executive function [43], [44]. Family-based care is often applied in society in various forms, for instance, care by one parent who is still alive, care with a continuing family contact and support from counselors in orphanages [45]. The care given by the assistants at this orphanage needs to be strengthened in the quality of the assistance provided, to replace the role of the biological family so that psychological problems that arise in the orphanage can be properly prevented.

Community health nurses work primarily in family and community settings, with the consequence that this practice takes place in group settings and performs different roles according to the type of group in progress. The nurse does not only play a role in the group but is also a member of the group. The role of the nurse is involved in various types of groups that focus on the here and now, do not focus on the past, apply recent learning in the group, adapt to new habits, increase or maintain levels of functioning, do not focus on developmental repetition, and are not a reconstruction of the group's personality [15]. Counselors believe that dynamic group and group processes help orphan adolescent express feelings and thoughts, can also help explore self-doubt and realization processes during group intervention sessions [45]. The use of group forums can further increase the effectiveness of the expected results. These types of groups can be combined with one another, and the role of peers in group activities is important for orphans to support their growth and development [46].

The results of this review indicate that one group-based intervention used more than 2 approaches in the group, for instance, in one intervention, the researcher used the support group approach, the self-help group, and the teaching-learning group. The interventions used in orphan groups and vulnerable children in Africa combine several interventions, which are mentorship, peer group support, educational interventions, social interventions, family support, and social interventions [35]. A comprehensive approach, by combining various approaches, both material and psychosocial supports such as interventions provided by Iritani et al. [47], shows significant results in increasing retention, school attendance, improving health, and improving children's well-being.

The strengths of this study have suggested that the combination of various group-based interventions provides more effective results, while the limitations of this study are the limited articles obtained that discuss emotional and behavioral problem interventions in orphans and the use of the term orphan is still unfamiliar in certain countries. Future review, it is necessary to review various studies and use appropriate synonyms for orphans.

\section{Conclusions}

This review revealed the emotional and behavioral problems experienced by orphan adolescents include depression, anxiety, and low self-esteem, followed by feeling of anger, depression, and trauma. Cognitive therapy, complementary and alternative medicine, and educational support are interventions that are mostly given to groups of orphaned adolescents with group-based emotional and behavioral problems. Teaching with learning group approaches is the most often used in the intervention of emotional and behavioral problems in orphan youth groups.

This review was limited to 10 research articles published in 2009-2019, with a sample of children and adolescents aged $7-20$ years. To identify the magnitude of emotional and behavioral problems in orphans, in the literature search process, it is necessary to add specific types of instruments that are often used to measure emotional and behavioral problems. To assess the appropriateness of the type of intervention based on child development, the next review needs to limit the age of the respondents to school age (6-12 years) and adolescence (over 12-20 years).

\section{References}

1. Rahman W, Mullick M, Pathan M, Chowdhury N, Shahidullah M, Ahmed $\mathrm{H}$, et al. Prevalence of behavioral and emotional disorders among the orphans and factors associated with these disorders. Bangabandhu Sheikh Mujib Med Univ J. 2012;5(1):29-34. https://doi.org/10.3329/bsmmuj.v5i1.10997

2. Zhao G, Zhao Q, Li X, Fang X, Zha J, Zhang L. Family-based care and psychological problems of AIDS orphans: Does it matter who was the care-giver? Psychol Heal Med. 2010;15(3):326-35. https://doi.org/10.1080/13548501003623989 PMid:20480436

3. Hagaman JL, Trout AL, Chmelka MB, Thompson RW, Reid R. Risk profiles of children entering residental care: A cluster 
analysis. J Child Fam Stud. 2010;19:525-35. https://doi. org/10.1007/s10826-009-9325-3

4. Gertler P, Martinez S, Levine D. Lost Presence and Presents: How Parental Death Affects Children. WPS Princet; 2004. Available from: http://www.weblamp.princeton.edu/chw/papers/ gertler.pdf. [Last accessed on 2021 August 05].

5. Mohammadzadeh M, Awang H, Hayati KS, Ismail S. The effects of a life skills-based intervention on emotional health, selfesteem and coping mechanisms in Malaysian institutionalised adolescents: Protocol of a multi-centre randomized controlled trial. Int J Educ Res. 2017;83:32-42. https://doi.org/10.1016/j. ijer.2017.02.010

6. EL Koumi MA, Ali YF, El Banna EA, Youssef UM, Yasser Raya M, Ismail AA. Psychiatric morbidity among a sample of orphanage children in Cairo. Int J Pediatr. 2012;2012:141854. https://doi. org/10.1155/2012/141854

PMid:23304169

7. Kaur R, Vinnakota A, Panigrahi S, Manasa R. A descriptive study on behavioral and emotional problems in orphans and other vulnerable children staying in institutional homes. Indian J Psychol Med. 2018;40:161-8. https://doi.org/10.4103/ijpsym. ijpsym_316_17

PMid:29962573

8. Mohammadzadeh M, Awang H, Ismail S, Shahar HK. Improving emotional health and self-esteem of Malaysian adolescents living in orphanages through Life Skills Education program: A multicentre randomized control trial. PLoS One. 2019;14(12):1-18. https://doi.org/10.1371/journal.pone.0226333

PMid:31877163

9. Johnson R, Browne K, Hamilton-Giachritsis C. Young children in institutional care at risk of harm. Trauma Violence Abus. 2006;7(1):34-60. https://doi.org/10.1177/1524838005283696 PMid:16332980

10. Vorria P, Papaligoura Z, Dunn J, van Ijzendoorn MH, Steele H, Kontopoulou A, et al. Early experiences and attachment relationships of Greek infants raised in residential group care. J Child Psychol Psychiatry Allied Discip. 2003;4(8):1208-20. https://doi.org/10.1111/1469-7610.00202

PMid:14626461

11. van ljzendoorn MH, Palacios J, Sonuga-Barke EJ, Gunnar MR, Vorria P, McCall RB. et al. Children in institutional care: Delayed development and resilience. Monogr Soc Res Child Dev. 2011;76(4):8-30.

PMid:25125707

12. Breslau J, Miller E, Breslau N, Bohnert K, Lucia V, Schweitzer J. The impact of early behavior disturbances on academic achievement in high school. Pediatrics. 2009;23(6):1472-6. https://doi.org/10.1542/peds.2008-1406

PMid:19482756

13. Groar CJ, Muhamedrahimov RJ, Palmov OI, Nikiforo NV, McCall RB. Improvements in early care in Russian orphanages and their relationship to observed behaviors. Infant Ment Health J. 2005;26(2):96-109. https://doi.org/10.1002/imhj.20041 PMid:28682520

14. Ojiambo, D, Bratton SC. Effects of group activity play therapy on problem behaviors of preadolescent Ugandan orphans. J Couns Dev. 2014;92(3):355-65. https://doi. org/10.1002/j.1556-6676.2014.00163.x

15. Logan BB, Dawkins CE. Familiy Centered Nursing in The Community. United States: Addison-Wesley Publisher; 1986.

16. VCU Libraries Research Guides. How To Conduct A Literature Review (Health Science). Virginia: VCU Libraries Research Guides; 2020.

17. Moher D, Liberati A, Tetzlaff J, Altman DG. Preferred reporting items for systematic reviews and meta-analyses: The PRISMA statement. BMJ. 2009;339:b2535.

18. Higgins J, Green S. Cochrane Handbook for Systematic Reviews of Intervention. West Sussex: John Willey and Sons Ltd.; 2008.

19. Peters MD, Moon Z, Moola S, Mishra RK. Guidance for conducting systematic scoping review. Int J Evid Based Healthc. 2015;13(3):141-6.

PMid:26134548

20. Cluver AK, Whetten K, Boyd LD, O'Donnell K. Yoga to reduce trauma-related distress and emotional and behavioral difficulties among children living in orphanages in Haiti: A pilot study. J Altern Complement Med. 2015;21(9):539-45.

21. Rouholamini M, Kalantarkousheh MS, Sharifi E. Effectiveness of spiritual components training on life satisfaction of Persian orphan adolescents. J Relig Health 2017;56(6):1895-902.

22. Kane CJ, Murray KL, Cohen J, Dorsey S, van Wyk SS, Henderson, et al. Moderators of treatment response to traumafocused cognitive behavioral therapy among youth in Zambia. J Child Psychol Psychiatry. 2016;57(10):1194-202.

23. Tejvani R, Metri K, Agrawal J, Nagendra H. Effect of Yoga on anxiety, depression and self-esteem in orphanage residents: A pilot study. Ayu 2016;37(1):22-5.

24. Green EP, Cho H, Gallis J, Puffer ES. The Impact of school support on depression among adolescent orphans: a clusterrandomized trial in Kenya. J Child Psychol Psychiatry. 2019;60(1):54-62.

25. Öztürk S, Ekinci M. The effect of structured education on selfesteem and the suicide probability of male adolescents living in orphanages. Arch Psychiatr Nurs. 2018;32(4)604-9.

26. Rahayu A, Keliat BA, Susanti $H$. The effectiveness of cognitive therapy and family psycho-education on prodromal psychosis and self-esteem of adolescents in orphanages. Enferm Clin. 2019;29(Suppl 2):10-5.

PMID:31253568

27. Levac D, Colquhoun H, O'Brien K. Scoping studies: Advancing the methodology. Implement Sci. 2010;5:69.

28. Atwine B, Cantor-Graae E, Bajunirwe F. Psychological distress amongAIDS orphans in ruralUganda. SocSciMed.2005;61(3):55564. https://doi.org/10.1016/j.socscimed.2004.12.018 PMid: 15899315

29. Cluver L, Gardner F, Operario D. Psychological distress amongst AIDS-orphaned children in urban South Africa. J Child Psychol Psychiatry. 2017;48(8):755-63. https://doi. org/10.1111/j.1469-7610.2007.01757.x PMid: 17683447

30. Donnell KO, Dorsey S, Gong W, Ostermann J, Whetten R, Cohen JA, et al. Treating maladaptive grief and posttraumatic stress symptoms in orphaned children in Tanzania: Group based trauma-focused cognitive-behavioral therapy. J Trauma Stress. 2014;27(3):664-71. https://doi.org/10.1002/jts.21970 PMid:25418514

31. Erol N, Simsek Z, Münir K. Mental health of adolescents reared in institutional care in Turkey: Challenges and hope in the twentyfirst century. Eur Child Adoles Psychiatry. 2010;19(2):113-24. https://doi.org/10.1007/s00787-009-0047-2 PMid:19644732

32. Erango MA, Ayka ZA. Psychosocial support and parents' social life determine the self-esteem of orphan children. Risk Manage Healthc Policy. 2015;8:169-73. https://doi.org/10.2147/rmhp. s89473

PMid:26508894

33. Santrock JW. Perkembangan Anak Jilid 1 Edisi Kesebalas. Jakarta: Erlangga; 2007.

34. Batubara JR. Adolescent development (Perkembangan Remaja). Sari Pediatr. 2010;12:789. 
35. Sitienei EC, Pillay J. Psycho-educational and social interventions provided for orphans and vulnerable children at a communitybased organisation in Soweto, South Africa. African J AIDS Res. 2019;18(1):1-8. https://doi.org/10.2989/16085906.2018.1548359 PMid:30668303

36. Larastiwi IA, Suerni TS. Pengaruh terapi rekreasi permainan crocodile river terhadap harga diri rendah situasional siswa di sma kesatrian 1 Semarang. J Ilmu Keperawatan dan Kebidanan. 2016;2016:1-11. https://doi.org/10.21776/ub.jik.2016.004.02.8

37. Alsubain M, Stain H, Webster LA, Wadman R. The role of sources of social support on depression and quality of life for university students. Int J Adolesc Youth. 2019;2:484-96. https:// doi.org/10.1080/02673843.2019.1568887

38. Neem F, Phiri P, Munshi T, Rathod S, Ayub M, Gobbi M. Cognitive behaviour therapy with South Asian Muslims: Findings from the culturally sensitive CBT project. J Int Rev Psychiatry. 2015;27:233-46.

PMid:26211879

39. De Arellano MA, Lyman DR, Jobe-Shields L, George P, Dougherty RH, Daniels AS, et al. Trauma-focused cognitivebehavioral therapy for children and adolescents: Assessing the evidence. Psychiatr Serv. 2014;65(5):591-602. PMid:24638076

40. Amirian ME, Fazilat-Pour M. Simple and multivariate relationships between spiritual intelligence with general health and happiness. J Relig Health. 2016;55(4):1275-88. https://doi. org/10.1007/s10943-015-0004-y

PMid:25616864

41. Mousavi B, Safarzadeh S. Effectiveness of the group play therapy on the insecure attachment and social skills of orphans in Ahvaz city. Int Educ Stud. 2016;9(9):42. https://doi. org/10.5539/ies.v9n9p42

42. Simpson JA, Rholes WS. Adult Attachment Orientations, Stress, and Romantic Relationships. $1^{\text {st }}$ ed., Vol. 45. Netherlands: Elsevier Inc.; 2012.

43. James-Palmer A, Anderson EZ, Zucker L, Kofman Y, Daneault JF. Yoga as an intervention for the reduction of symptoms of anxiety and depression in children and adolescents: A systematic review. Front Pediatr. 2020;8:1-16. https://doi.org/10.3389/ fped.2020.00078

PMid:32232017

44. Purohit SP, Pradhan B. Effect of yoga program on executive functions of adolescents dwelling in an orphan home: A randomized controlled study. J Tradit Complement Med. 2017;7(1):99-105. https://doi.org/10.1016/j.jtcme.2016.03.001 PMid:28053894

45. Embleton L, Ayuku D, Kamanda A, Atwoli L, Ayaya S, Vreeman R, et al. Models of care for orphaned and separated children and upholding children's rights: Cross-sectional evidence from western Kenya. BMC Int Health Hum Rights. 2014;14(1):1-18. https://doi.org/10.1186/1472-698x-14-9

46. Madihie A, Noah SM. An application of the Sidek module development in Rebt counseling intervention module design for orphans. Proc Soc Behav Sci. 2013;84:1481-91. https://doi. org/10.1016/j.sbspro.2013.06.777

47. Iritani BJ, Cho H, Rusakaniko S, Mapfumo J, Hartman S, Hallfors DD. Educational outcomes for orphan girls in rural Zimbabwe: Effects of a school support intervention. Health Care Women Int. 2016;37(3):301-22. https://doi.org/10.1080/073993 32.2015.1017641

PMid:25692731

\section{Author Queries???}

AQ4: Kindly cite reference 27 in text part and also cite in chronological order 